\title{
Protein sources and digestive enzyme activities in jundiá (Rhamdia quelen)
}

\author{
Rafael Lazzarii ; João Radünz Neto ${ }^{1 *}$; Fabio de Araújo Pedron ${ }^{1}$; Vania Lucia Loro ${ }^{2}$; \\ Alexandra Pretto ${ }^{2}$; Carolina Rosa Gioda ${ }^{3}$ \\ ${ }^{1}$ UFSM - Depto. de Zootecnia, Campus Universitário, Av. Roraima, 1000 - 97105-900 - Santa Maria, RS - \\ Brasil. \\ ${ }^{2}$ UFSM - Depto. de Química - Lab. de Bioquímica Adaptativa. \\ ${ }^{3}$ UFMG - Instituto de Ciências Biológicas, Av. Antônio Carlos, 6627 - Pampulha - 31270-901 - Belo Horizonte, \\ $M G-$ Brasil. \\ *Corresponding author <jradunzneto@yahoo.com.br>
}

\begin{abstract}
Digestive enzymes activity influence feed utilization by fish, and its understanding is important to optimize diet formulation. This study reports the digestive enzyme activities of jundiá juveniles fed diets with protein sources. Fish were fed six experimental diets for 90 days: MBY (meat and bone meal + sugar cane yeast), SY (soybean meal + sugar cane yeast), S (soybean meal), MBS (meat and bone meal + soybean meal), FY (fish meal + sugar cane yeast) and FS (fish meal + soybean meal), and then sampled every 30 days and assayed in two intestine sections for digestive enzymes - trypsin, chymotrypsin and amylase - activities; gastric protease was assayed in the stomach. Digestive and hepatosomatic index, intestinal quotient, digestive tract length and weight gain were also measured. Trypsin and chymotrypsin activities were higher $(p<0.0001)$ in fish fed diets containing animal protein sources (MBY, MBS, FY and FS diets). Alkaline proteases were negatively affected by dietary soybean meal in the SY and S diets. Amylase activity had greater variation between diets and intestine sections. Fish fed MBY and MBS diets showed higher gastric protease activity $(p<0.0001)$. Weight gains were higher in fish fed the MBS and FS diets $(p<0.05)$. Highest values $(p<0.05)$ of digestive tract length were observed in fish fed MBS and FY diets, but no correlation with enzymes activities was found. Hepatosomatic index (HSI) was affected by diet composition. Dietary composition influenced digestive enzymes activities of jundiá.
\end{abstract}

Key words: digestion, nutrition, soybean meal, meat and bone meal, fish meal

\section{Fontes protéicas e atividade de enzimas digestivas em jundiás (Rhamdia quelen)}

\begin{abstract}
RESUMO: As enzimas digestivas influenciam a utilização dos alimentos em peixes, e seu conhecimento é importante para otimizar a formulação de dietas. Este trabalho descreve a atividade de enzimas digestivas em juvenis de jundiá alimentados com fontes protéicas. Os peixes foram alimentados com seis dietas ( 90 dias): MBY (farinha de carne e ossos + levedura de cana), SY (farelo de soja + levedura de cana), S (farelo de soja), MBS (farinha de carne e ossos + farelo de soja), FY (farinha de peixe + levedura de cana) e FS (farinha de peixe + farelo de soja). A cada 30 dias, foram analisadas as enzimas digestivas (tripsina, quimiotripsina e amilase) no intestino. No estômago, foi mensurada a protease ácida. Foram estimados os índices digestivo e hepato-somático, quociente intestinal, comprimento do trato digestório e ganho em peso. As atividades de tripsina e quimiotripsina foram maiores $(p<0,0001)$ nos peixes alimentados com as dietas com fontes de origem animal (MBY, MBS, FY e FS). As proteases alcalinas foram afetadas negativamente pelo farelo de soja nas dietas. A atividade de amilase apresentou grandes variações. Os peixes alimentados com as dietas MBY e MBS apresentaram maior atividade de protease ácida $(p<0,0001)$. Os ganhos em peso foram maiores nos peixes alimentados com as dietas MBS e FS $(p<0,05)$. Os maiores valores $(p<0,05)$ de comprimento do trato digestório foram verificados nos peixes alimentados com as dietas MBS e FY. A composição da dieta influencia na atividade de enzimas digestivas do jundiá.
\end{abstract}

Palavras-chave: digestão, nutrição, farelo de soja, farinha de carne e ossos, farinha de peixe

\section{Introduction}

The study of digestive enzymes is an essential step towards understanding the mechanism of digestion and how organisms adapt to changes in the nutritional environment (Sunde et al., 2004). Digestive enzyme activities of fish are associated with innate feeding habit and diet composition (Ray, 1988). Factors such as age, $\mathrm{pH}$, temperature, and anatomic-physiological characteristics also influence the digestive enzyme activity (Kuz'mina, 1990; 1996). Usually, carnivorous fish present higher protease activity while carbohydrases are more active in omnivorous and herbivorous fishes (Ugolev and Kuz'mina, 1994). Studies concerning digestive enzymes of fish can 
elucidate some aspects of their nutritional physiology (Uys and Hecht, 1987).

The need for optimizing the production of aquafeeds has taken several researchers to evaluate alternative protein sources with homogeneous composition, low cost and good nutrient balance. Animal protein sources are regularly used in feeds, because they present good essential amino acids balance (Tacon, 1993). However, higher costs and heterogeneous composition repeatedly limit their use, and the use of alternative sources is required (Webster et al., 1995).

Jundiá (Rhamdia quelen) is a native catfish to Southern Brazil, an omnivorous fish feeding on small fish, crustaceans, and vegetable debris in the nature (Gomes et al., 2000). Under farming conditions, jundiá readily accepts various processed aquafeeds, and shows resiliency and high productive potential (Barcellos et al., 2004). A great proportion of the available information on nutrient digestion and teleost digestive enzyme profiles and performance refers to environmental conditions, especially temperature, not encountered in nature by most species (Papoutsoglou and Lyndon, 2005). Thus, this study aimed to investigate the digestive enzyme activities in jundiá juveniles fed diets containing different protein sources.

\section{Material and Methods}

\section{Fish and experimental diets}

The feeding trial was carried out in Santa Maria, Rio

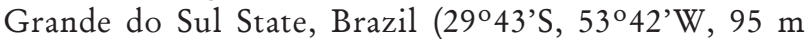
a.s.l.). Five hundred and forty jundiá juveniles (15.00 \pm $0.62 \mathrm{~g} ; 11.98 \pm 0.35 \mathrm{~cm})$ obtained by induced spawning were randomly distributed in 18, 280-L tanks (30 fish pertank) in a water recirculation system with biological filters (Radünz Neto et al., 1987), a completely randomized experimental design $(n=3)$. Fish were acclimated to the experimental conditions for one week and subsequently fed the experimental diets during 90 days, twice a day (9h00 and 17h00 h), to apparent satiation.

Six diets were tested : MBY - meat and bone meal + sugar cane yeast; SY - soybean meal + sugar cane yeast; $S$ - soybean meal; MBS - meat and bone meal + soybean meal; FY - fish meal + sugar cane yeast; and FS - fish meal + soybean meal, formulated to meet Coldebella and Radünz Neto (2002) creteria.. Dry ingredients were ground, mixed and added of canola oil. Water was added at $250 \mathrm{~g} \mathrm{~kg}^{-1}$ of mixture. The mixtures were then pelleted and dried in oven at $57^{\circ} \mathrm{C}$ for $24 \mathrm{~h}$. Pellets were packed in plastic bags and kept at $-20^{\circ} \mathrm{C}$ until use. Formulation and composition of experimental diets are presented in Tables 1 and 2.

The following water quality parameters were measured daily and were within the limits appropriate for fish production (Gomes et al., 2000): temperature (26.85 $\left.\pm 1.02{ }^{\circ} \mathrm{C}\right), \mathrm{pH}(7.30 \pm 0.26)$, dissolved oxygen $(5.53 \pm$ $\left.0.62 \mathrm{mg} \mathrm{L}^{-1}\right)$, alkalinity $\left(48.96 \pm 13.40 \mathrm{mg} \mathrm{CaCO}_{3} \mathrm{~L}^{-1}\right)$, total ammonia $\left(0.50 \pm 0.22 \mathrm{mg} \mathrm{L}^{-1}\right)$ and nitrite $(0.06 \pm 0.01$ $\left.\mathrm{mg} \mathrm{L}^{-1}\right)$. Tanks were cleaned by siphoning out feces and food residues every day. Fish were individually weighed at the end of the experiment.

\section{Tissue samples}

Every 30 days, three juveniles per tank were captured for excision of digestive tract and liver. Fish fasted for $24 \mathrm{~h}$ before collection and were sacrificed by spinal cord

Table 1 - Formulation of experimental diets.

\begin{tabular}{|c|c|c|c|c|c|c|}
\hline \multirow{2}{*}{ Ingredient } & \multicolumn{6}{|c|}{$\operatorname{Diet}^{1}$} \\
\hline & MBY & SY & S & MBS & FY & FS \\
\hline & 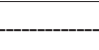 & - & 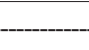 & - & - & 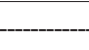 \\
\hline Sugar cane yeast & 280 & 332.7 & - & - & 259.2 & - \\
\hline Meat and bone meal & 385.3 & - & - & 300 & - & - \\
\hline Fish meal & - & - & - & - & 300.6 & 224.8 \\
\hline Soybean meal & - & 332.7 & 685.3 & 320 & - & 300 \\
\hline Corn grain & 150 & 134.4 & 124.5 & 169.5 & 200 & 195 \\
\hline Wheat flour & 80 & 100 & 100 & 80.3 & 150 & 180 \\
\hline Canola oil & 74.5 & 70 & 60 & 100 & 60 & 70 \\
\hline Salt & 10 & 10 & 10 & 10 & 10 & 10 \\
\hline Dicalcium phosphate & 10 & 10 & 10 & 10 & 10 & 10 \\
\hline Vitamin/mineral mixture ${ }^{2}$ & 10 & 10 & 10 & 10 & 10 & 10 \\
\hline Antioxidant ${ }^{3}$ & 0.2 & 0.2 & 0.2 & 0.2 & 0.2 & 0.2 \\
\hline
\end{tabular}

${ }^{1}$ Diets: MBY: meat and bone meal + sugar cane yeast; SY: soybean meal + sugar cane yeast; S: soybean meal; MBS: meat and bone meal + soybean meal; FY: fish meal + sugar cane yeast; FS: fish meal + soybean meal. ${ }^{2}$ Vitamin/mineral mixture (kg product): Vit.A: $6000000 U I ;$ Vit.B1: 1400 mg; Vit.B2: 3375 mg; Vit.B6: 4830 mg; Vit.B12: 5000 mcg; Vit.C: 25000 mg; Vit.D3: 530000UI; Vit.E: 22500 mg; Vit.K3: 5000 mg; Zinc: 40000 mg. Folic acid: 400mg; Nicotinic acid: 14000mg; Cobalt: 1500mg; Pantothenic acid: 8000 mg; Copper: 15000 mg; Colin: 1500 mg; Iron: 50000 mg; Iodine: 700 mg; Manganese: 23000mg; Selenium: 250mg; ${ }^{3}(32 \%$ etoxiquin. $18 \%$ propyl-galate. $50 \%$ inert). 
Table 2 - Proximate and amino acids composition of the experimental diets.

\begin{tabular}{|c|c|c|c|c|c|c|}
\hline & \multicolumn{6}{|c|}{ Diet $^{1}$} \\
\hline & MBY & SY & $\mathrm{S}$ & MBS & FY & FS \\
\hline \multicolumn{7}{|c|}{ Proximate analysis (\% in dry matter) } \\
\hline Crude protein & 34.67 & 32.14 & 33.03 & 34.45 & 32.92 & 31.92 \\
\hline Ash & 13.24 & 5.27 & 6.23 & 12.98 & 9.98 & 10.7 \\
\hline Crude lipid & 12.75 & 8.0 & 7.2 & 16.4 & 9.83 & 11.42 \\
\hline Crude fiber & 1.80 & 3.09 & 4.23 & 3.67 & 1.83 & 3.68 \\
\hline Moisture & 6.94 & 7.91 & 8.95 & 5.52 & 6.50 & 8.00 \\
\hline $\mathrm{NFE}^{2}$ & 37.54 & 51.50 & 49.31 & 32.5 & 45.44 & 42.28 \\
\hline Calcium & 3.49 & 1.36 & 1.59 & 3.00 & 2.16 & 2.16 \\
\hline Phosphorus & 2.01 & 0.75 & 0.87 & 1.84 & 1.57 & 1.58 \\
\hline Digestible energy ${ }^{3}\left(\mathrm{kcal} \mathrm{kg}^{-1}\right)$ & 3417.7 & 3173.9 & 3087.9 & 3628.0 & 3267.1 & 3248.0 \\
\hline \multicolumn{7}{|l|}{ Amino acids $(\% \text { in diet })^{4}$} \\
\hline Arginine & 1.79 & 1.84 & 2.54 & 2.15 & 1.70 & 2.11 \\
\hline Phenylalanine & 1.04 & 1.48 & 1.86 & 1.28 & 1.29 & 1.49 \\
\hline Histidine & 0.52 & 0.75 & 0.95 & 0.65 & 0.95 & 1.00 \\
\hline Isoleucine & 1.00 & 1.45 & 1.60 & 1.07 & 1.31 & 1.33 \\
\hline Lysine & 2.08 & 2.02 & 2.14 & 1.94 & 2.10 & 2.00 \\
\hline Leucine & 1.80 & 2.28 & 2.60 & 1.95 & 2.28 & 2.35 \\
\hline Methionine + cystine & 0.81 & 0.84 & 1.03 & 0.87 & 0.92 & 0.98 \\
\hline Threonine & 1.14 & 1.44 & 1.40 & 1.04 & 1.43 & 1.28 \\
\hline Tryptophan & 0.13 & 0.27 & 0.47 & 0.28 & 0.27 & 0.40 \\
\hline Valine & 1.32 & 1.61 & 1.72 & 1.31 & 1.59 & 1.55 \\
\hline
\end{tabular}

${ }^{1}$ Diets: MBY: meat and bone meal + sugar cane yeast; SY: soybean meal + sugar cane yeast; S: soybean meal; MBS: meat and bone meal + soybean meal; FY: fish meal + sugar cane yeast; FS: fish meal + soybean meal. ${ }^{2}$ Nitrogen free extract calculated by difference. ${ }^{3} \mathrm{DE}=\left[\left(23.6 \mathrm{~kJ} \mathrm{~g}^{-1} \times \%\right.\right.$ Protein $\left.\times 0.9\right)+\left(39.8 \mathrm{~kJ} \mathrm{~g}^{-1} \times \%\right.$ Lipids $\left.\times 0.85\right)+\left(17.2 \mathrm{~kJ} \mathrm{~g}^{-1} \times \%\right.$ Cho $\left.\left.\times 0.5\right)\right] / 100$, when $1 \mathrm{KJ}=0.239 \mathrm{kcal}$. ${ }^{4}$ Calculated values.

puncture, weighted and eviscerated for separation of digestive tract. The digestive tract was measured, weighted and separated in three sections: stomach, anterior and posterior intestines. The sections were immediately stored at $-20^{\circ} \mathrm{C}$. Later, each section was dissected in a Petri dish containing saline solution $(0.7 \%, \mathrm{NaCl})$, the digestive content was discarded and the sections were homogenized $(1000 \times \mathrm{g})$ for $2 \mathrm{~min}$ in a van Potter_Elvehjem tissue homogenizer with buffer solution $\mathrm{pH}$ 7.0. The samples were then centrifuged at 12000 $\times \mathrm{g}$ for $5 \mathrm{~min}\left(4^{\circ} \mathrm{C}\right)$ and the supernatant was used as enzyme source.

\section{Enzyme assays}

At 30 days in the experiment, fish were sampled and the activity of acid protease measured in the stomach, and the activity of amylase, trypsin and chymotrypsin measured in two intestinal sections. Total acid protease activity was measured using non-specific substrate (casein) according to Kunitz (1947), with modifications by Hidalgo et al. (1999). The assay was carried out using $0.2 \mathrm{M} \mathrm{KCl}$ buffer, $\mathrm{pH}$ 2.0. The absorbance of the enzyme extract had recorded at $280 \mathrm{~nm}$. All samples were assayed in duplicate and readings corrected for blank solutions. Tyrosine was used as standard, and one unit of enzyme was defined as the amount of enzyme needed to catalyze the formation of $1.0 \mathrm{mg}$ of tyrosine per min per $\mathrm{mg}$ protein, according to Hidalgo et al. (1999). Alkaline protease, trypsin, chymotrypsin and a-amylase were determined in homogenates from intestinal sections. Trypsin activity (E.C.3.4.21.4) was assayed with a-r-toluenesulphonyl-Larginine methyl ester hydrochloride (TAME). Crude extracts were incubated for $2 \mathrm{~min}\left(25^{\circ} \mathrm{C}\right)$ in $2 \mathrm{~mL}$ of Tris $/ \mathrm{CaCl}_{2}$ buffer, $\mathrm{pH}$ 8.1. Chymotrypsin activity (E.C.3.4.21.1) was assayed with benzoyl tyrosine ethyl ester (BTEE). Crude extracts were incubated for 2 min in $2 \mathrm{~mL}$ of Tris $/ \mathrm{CaCl}_{2}$ buffer, $\mathrm{pH}$ 7.8. Both trypsin and chymotrypsin were assayed in duplicate and enzyme activities were recorded at 247 and 256 $\mathrm{nm}$, respectively, according to protocol by Hummel (1959). One unit of enzyme was defined as the amount of enzyme needed to hydrolyze $1 \mathrm{mg}$ of substrate (TAME or BTEE) per min per mg protein. Activity of a-amylase was assayed in $0.2 \mathrm{M}$ phosphate-citrate buffer, $\mathrm{pH} 7.0,0.5 \% \mathrm{NaCl}$ with a starch concentration of $2.5 \%$. The reaction was stopped by adding $\mathrm{Ba}(\mathrm{OH})_{2}$ $0.3 \mathrm{~N}$ and $\mathrm{ZnSO}_{4} 5 \%$. The experimental protocol was 
modified according to Bernfeld (1955). The determination of starch hydrolysis was done following Park and Johnson (1949). The absorbance was recorded at $660 \mathrm{~nm}$. One unit of enzyme was defined as $1 \mathrm{mmol}$ of glucose released from starch per min per mg of protein. Protein content of crude extracts was determined by the method of Lowry et al. (1951), using bovine serum albumin as a standard.

\section{Calculations}

Digestive somatic index $(\mathrm{DSI})=$ (digestive tract weight/body weight) $\times 100$; Hepatosomatic index $(\mathrm{HSI})$ $=($ liver weight/body weight $) \times 100$; Digestive tract length $(\mathrm{DTL})=$ expressed in $\mathrm{cm}$; Intestinal quotient (IQ) = digestive tract length/total fish length; Weight gain $(\mathrm{WG})=($ final weight - initial weight $)$, in $\mathrm{g}$.

\section{Statistical analysis}

Data were assessed for normality using a ShapiroWilk test and submitted to one-way ANOVA. Data on activity amylase, trypsin and chymotrypsin were submitted to two-way ANOVA, intestine sections considered in the model. Means were compared by Duncan test $(\alpha=0.05)$, and values expressed as mean \pm standard error $(n=3)$. All statistics were carried out using SAS (1997) software.

\section{Results}

The activity of digestive enzymes of jundiá juveniles varied with diet composition (Figures 1, 2 and $3)$. A decrease $(p<0.0001)$ in trypsin and chymotrypsin activities was detected in jundiá fed diets without animal source feedstuffs, i. SY and S diets (Figures 1 and 2) in both intestine sections and in all sampling periods. Trypsin activity at the end of the experiment was higher in the anterior intestine (Figure $1 \mathrm{C})$. The higher trypsin activity $(p<0.0001)$ after 30 and 60 days was observed in fish fed FS, MBY and MBS diets (Figures 1A and 1B). At 90 days, fish fed diets containing feedstuffs of animal origin combined with soybean meal (MBS and FS) had higher trypsin activity $(p<0.0001)$.

Chymotrypsin activities were higher in fish fed MBS and FS diets after 30 and 60 feeding days (Figures 2A and $2 \mathrm{~B}$ ). At the end of trial (Figure 2C), fish fed FS diet had higher chymotrypsin activity $(p<0.0001)$ in the anterior intestine. In the posterior intestine (Figure 2C), higher chymotrypsin activities were found in fish fed MBS and fish meal-based diets (FY and FS).

The amylase activitiy showed great variation between feeding periods, intestine sections and diets (Figure 3). At 30 days of trial, higher amylase activities were found in fish fed FS and MBS diets $(p<0.0001)$. In the posterior intestine (Figure $3 \mathrm{~A}$ ), lower amylase activities were found in fish fed MBY, SY and S diets. Higher amylase secretion was observed after 60 days in the anterior intestine of jundia fed FY, FS, and MBS diets, and in the posterior intestine of fish fed MBS diet
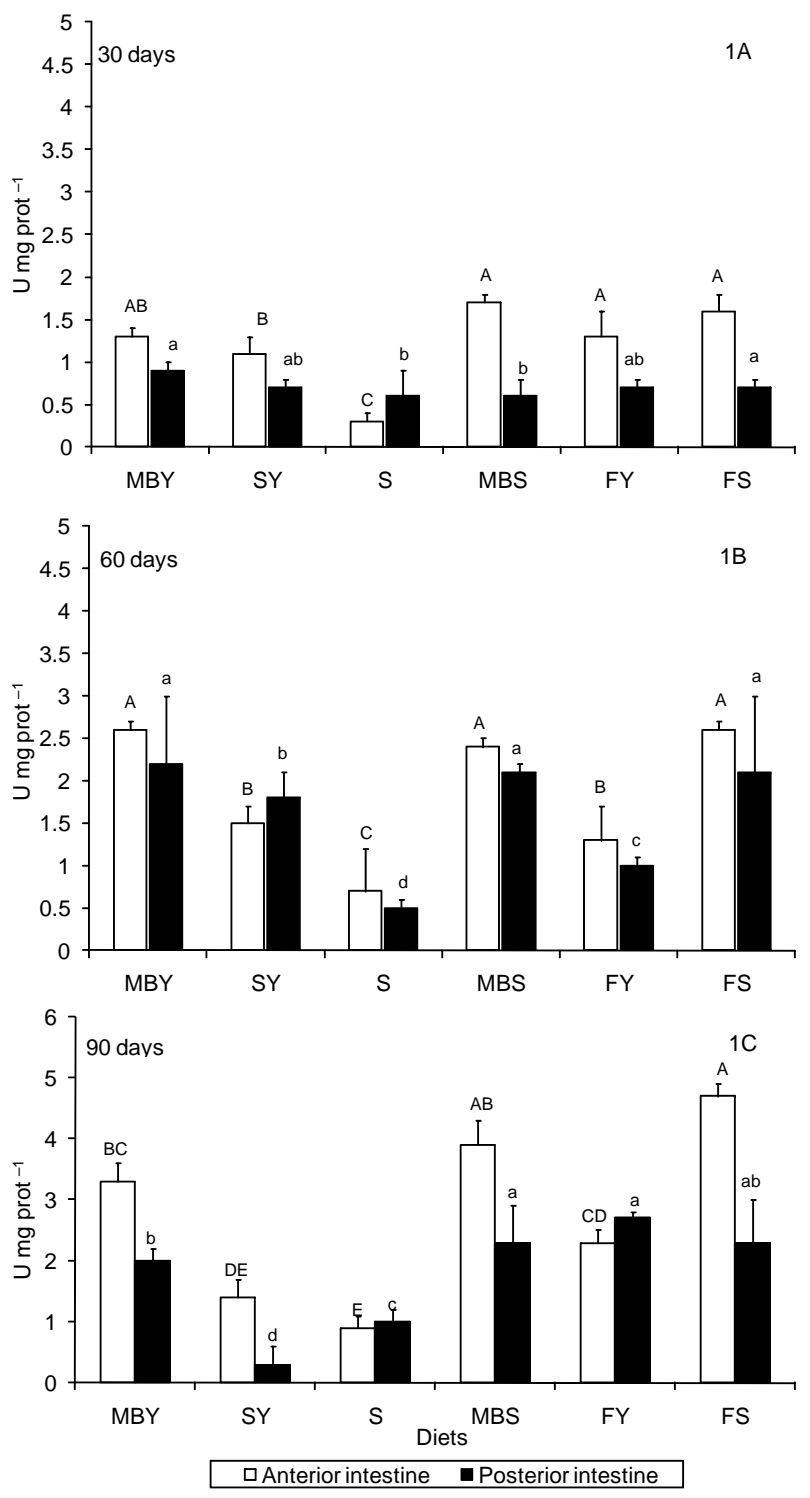

Figure 1 - Trypsin activity $\left(\mathrm{U} \mathrm{mg}^{-1} \mathrm{prot}\right)$ in intestine of jundiá after $30(1 \mathrm{~A}), 60(1 \mathrm{~B})$ and $90(1 \mathrm{C})$ days of feeding diets with different protein sources. Values showed as mean $\pm \operatorname{SEM}(\mathrm{n}=3)$. $* \mathrm{U}=\mu \mathrm{mol}$ of substrate (TAME) hydrolyzed per min per mg of protein. Diets: MBY: meat and bone meal + sugar cane yeast; $S Y$ : soybean meal + sugar cane yeast; $S$ : soybean meal; MBS: meat and bone meal + soybean meal; FY: fish meal + sugar cane yeast; FS: fish meal + soybean meal. Capital letters indicate difference between diets in the anterior intestine and smaller letters represent difference in the posterior intestine (Duncan's test, $p<0.0001$ ).

(Figure 3B). At 90 days, fish fed the MBY diet showed higher amylase activity in the anterior intestine while in fish fed S diet amylase activity was lower (Figure 3C). In the posterior intestine, lower amylase was found in fish fed SY diet. No differences were observed between amylase activities in anterior and posterior intestines of jundiá $(p>0.05)$. The acid protease activi- 

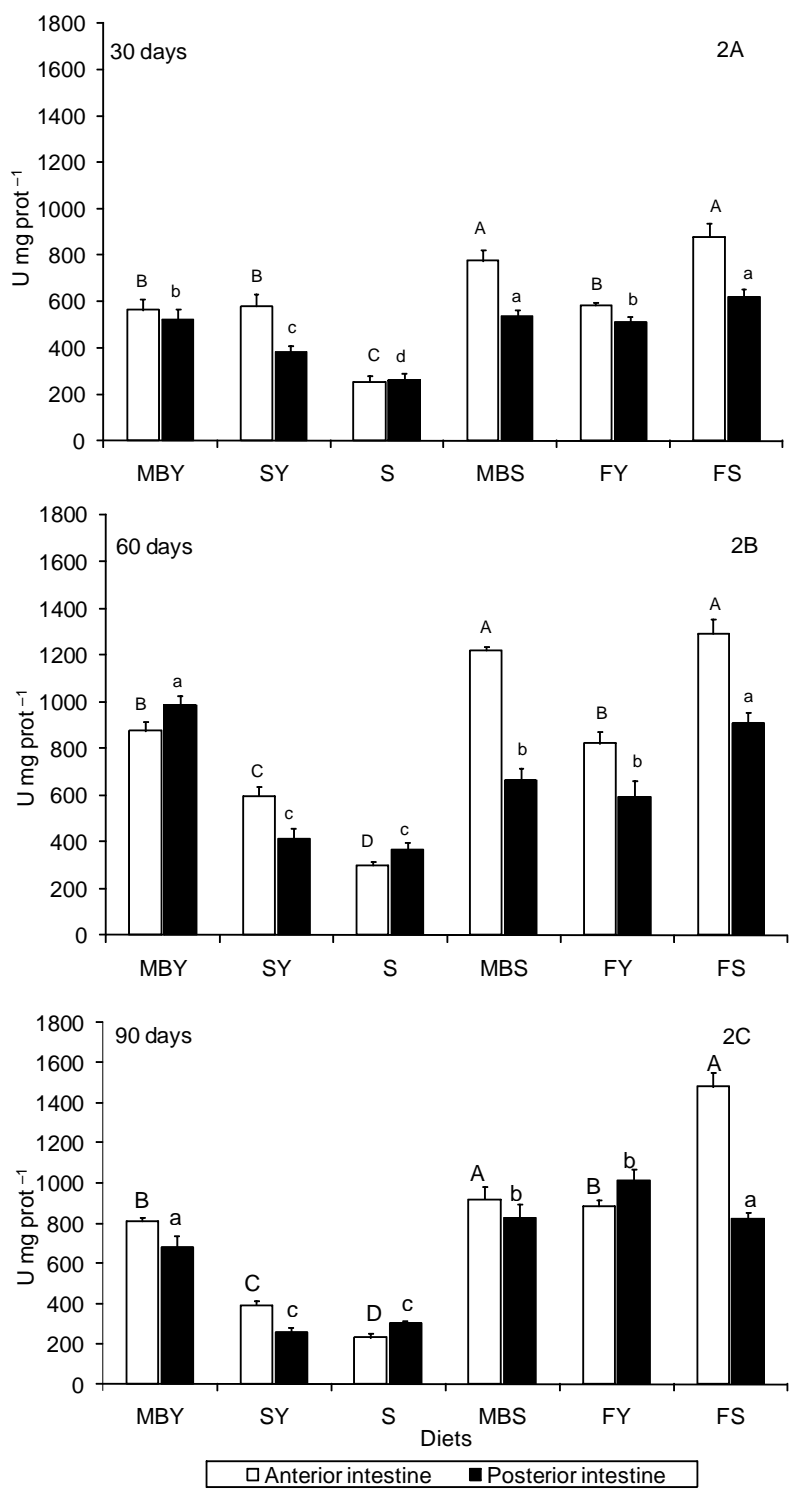

Figure 2 - Chymotrypsin activity $\left(\mathrm{U} \mathrm{mg}^{-1}\right.$ prot $)$ in intestine of jundiá after $30(2 \mathrm{~A}), 60(2 \mathrm{~B})$ and $90(2 \mathrm{C})$ feeding days. Values showed as mean $\pm \operatorname{SEM}(\mathrm{n}=3)$. $* \mathrm{U}=$ $\mu \mathrm{mol}$ of substrate (BTEE) hydrolyzed per min per mg of protein. Diets: MBY: meat and bone meal + sugar cane yeast; SY: soybean meal + sugar cane yeast; S: soybean meal; MBS: meat and bone meal + soybean meal; FY: fish meal + sugar cane yeast; FS: fish meal + soybean meal. Capital letters indicate significant difference between diets in the anterior intestine and smaller letters represent difference in the posterior intestine by Duncan's test $(p<0.0001)$.

ties were higher $(p<0.0001)$ in fish fed MBS and FS diets at 30 days of trial (Table 3). At 60 days, fish fed only soybean meal (diet $S$ ) showed lower acid protease activity. Fish fed diets containing meat and bone meal (MBS and MBY) showed higher acid protease activities at the end of trial (Table 3).

No differences were observed in the DSI values of jundiá (Table 4). The hepatosomatic index, total diges-
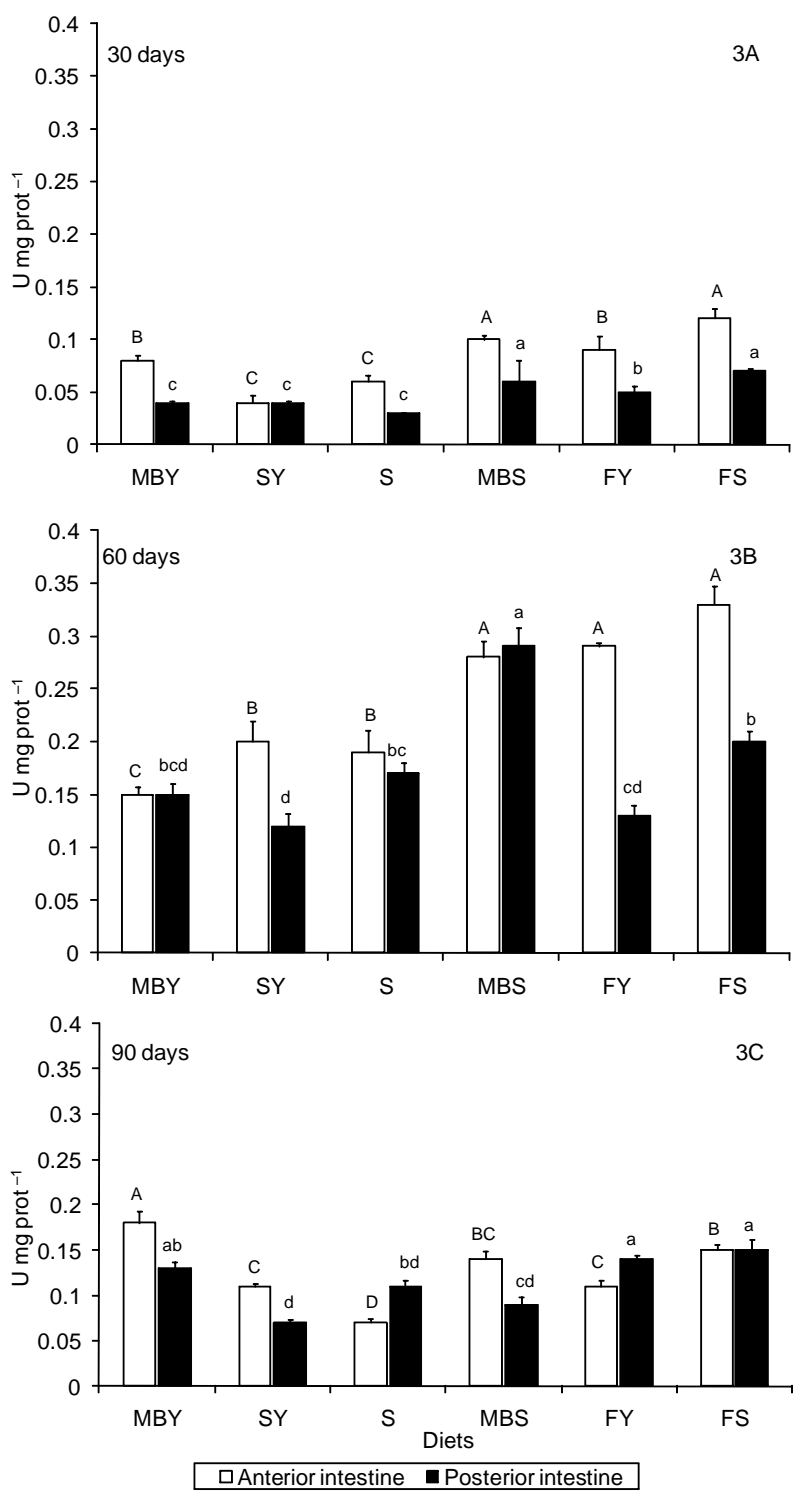

Figure 3 - Amylase activity $\left(\mathrm{U} \mathrm{mg}^{-1}\right.$ prot $)$ in intestine of jundiá after $30(3 \mathrm{~A}), 60(3 \mathrm{~B})$ and 90 (3C) feeding days. Values showed as mean $\pm \operatorname{SEM}(\mathrm{n}=3)$. $* \mathrm{U}=\mu \mathrm{mol}$ substrate hydrolyzed per min per mg of protein. Diets: MBY: meat and bone meal + sugar cane yeast; SY: soybean meal + sugar cane yeast; S: soybean meal; MBS: meat and bone meal + soybean meal; FY: fish meal + sugar cane yeast; FS: fish meal + soybean meal. Capital letters indicate significant difference between diets in the anterior intestine and smaller letters represent difference in the posterior intestine by Duncan's test $(p<0.0001)$.

tive tract length and intestinal quotient were higher in fish fed the MBS diet $(p<0.05$, Table 4$)$. Values of intestinal quotient were lower in fish fed diets without the inclusion of animal protein sources (SY and S diets). Higher weight gain values $(p<0.05)$ were obtained in fish fed MBS and FS diets ( 95.5 and $94.1 \mathrm{~g}$, respectively). The juvenile jundia fed the soybean meal based diet (S diet) showed lower weight gain $(15.8 \mathrm{~g})$. 
Table 3 - Acid protease activity in stomach of jundiá juveniles fed diets with protein sources.

\begin{tabular}{|c|c|c|c|}
\hline Diet & 30 days & 60 days & 90 days \\
\hline & \multicolumn{3}{|c|}{ 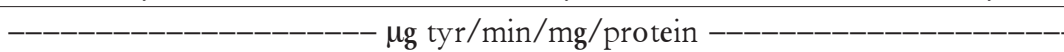 } \\
\hline MBY & $47.7^{c} \pm 1.5$ & $74.9^{a} \pm 6.5$ & $55.8^{\mathrm{a}} \pm 2.5$ \\
\hline SY & $33.9^{\mathrm{d}} \pm 0.8$ & $64.8^{\mathrm{ab}} \pm 2.5$ & $49.9^{\mathrm{b}} \pm 1.8$ \\
\hline S & $61.8^{\mathrm{b}} \pm 2.7$ & $45.5^{c} \pm 3.9$ & $37.7^{c} \pm 2.1$ \\
\hline MBS & $74.3^{\mathrm{a}} \pm 2.2$ & $58.5^{b} \pm 2.0$ & $56.6^{\mathrm{a}} \pm 1.6$ \\
\hline FY & $43.8^{c} \pm 1.7$ & $54.4^{\mathrm{bc}} \pm 0.9$ & $31.5^{\mathrm{d}} \pm 0.8$ \\
\hline FS & $71.4^{a} \pm 3.1$ & $74.2^{\mathrm{a}} \pm 2.9$ & $35.0^{\text {cd }} \pm 1.4$ \\
\hline
\end{tabular}

Values are showed as mean \pm standard error $(\mathrm{n}=3)$. Means with different superscripts letters in the columns showed difference by Duncan test $(p<0.0001)$. Diets: MBY: meat and bone meal + sugar cane yeast; SY: soybean meal + sugar cane yeast; S: soybean meal; MBS: meat and bone meal + soybean meal; FY: fish meal + sugar cane yeast; FS: fish meal + soybean meal.

Table 4 - Digestive and growth parameters in jundiá juveniles fed diets with different protein sources.

\begin{tabular}{lccccc}
\hline Diets & DSI & HSI & DTL & IQ & WG \\
\hline & $2.2 \pm 0.21^{\mathrm{a}}$ & $0.8 \pm 0.12^{\mathrm{b}}$ & $16.5^{\mathrm{bc}} \pm 1.5$ & $0.8^{\mathrm{ab}} \pm 0.0$ & $\mathrm{~g}$ \\
MBY & $2.4 \pm 0.13^{\mathrm{a}}$ & $0.7 \pm 0.06^{\mathrm{b}}$ & $13.6^{\mathrm{bc}} \pm 1.4$ & $0.7^{\mathrm{b}} \pm 0.39$ \\
SY & $2.6 \pm 0.13^{\mathrm{a}}$ & $0.9 \pm 0.04^{\mathrm{ab}}$ & $13.0^{\mathrm{c}} \pm 0.96$ & $0.7^{\mathrm{b}} \pm 0.04$ & $54.2^{\mathrm{c}} \pm 2.76$ \\
S & $2.4 \pm 0.13^{\mathrm{a}}$ & $1.0 \pm 0.06^{\mathrm{a}}$ & $20.2^{\mathrm{a}} \pm 1.27$ & $0.9^{\mathrm{a}} \pm 0.07$ & $95.5^{\mathrm{a}} \pm 3.65$ \\
MBS & $2.2 \pm 0.11^{\mathrm{a}}$ & $0.9 \pm 0.05^{\mathrm{ab}}$ & $17.3^{\mathrm{ab}} \pm 1.1$ & $0.8^{\mathrm{ab}} \pm 0.05$ & $75.3^{\mathrm{b}} \pm 1.58$ \\
FY & $2.4 \pm 0.19^{\mathrm{a}}$ & $0.8 \pm 0.12^{\mathrm{b}}$ & $16.2^{\mathrm{bc}} \pm 1.4$ & $0.8^{\mathrm{ab}} \pm 0.06$ & $94.1^{\mathrm{a}} \pm 1.73$ \\
\hline FS & & &
\end{tabular}

Values are showed as mean \pm standard error $(\mathrm{n}=3)$. DSI: digestive somatic index; HSI: hepatosomatic index; DTL: digestive tract length; IQ: intestinal quotient; WG: weight gain. Diets: MBY: meat and bone meal + sugar cane yeast; SY: soybean meal + sugar cane yeast; S: soybean meal; MBS: meat and bone meal + soybean meal; FY: fish meal + sugar cane yeast; FS: fish meal + soybean meal. Means with different superscripts letters in the columns showed difference by Duncan test $(p<0.05)$.

\section{Discussion}

Fish fed the SY and S diets had lower trypsin and chymotrypsin activities demonstrating the negative effect of soybean meal in both intestine sections. Several authors actually show that higher dietary soybean meal levels result in lower trypsin activity and reduced growth rates in fish decrease (Oliva-Teles et al., 1994; Olli et al., 1994; Refstie et al., 1998; Krogdahl et al., 2003). Trypsin and chymotrypsin activities can be used for the prediction of dietary protein quality or the digestive ability of the organism, which may in turn lead to differences in growth rate (Sunde et al., 2004). The highest alkaline protease activities registered for fish fed diets with animal protein sources (mainly MBS and FS diets) may be explained by the quality of protein of these ingredients. In consequence, fish fed these diets had higher weight gains. Trypsin activity has been shown to influence growth rate in Atlantic cod (Lemieux et al., 1999) and Atlantic salmon (Sunde et al., 2004).

The digestive enzymes response can be also influenced by the feeding period, as changes in protein synthesis and enzyme activity in fishes can be observed after a long feeding period (Krogdahl et al., 1994; Kaushik et al., 1995; López et al., 1999). Measuring the activity of digestive enzymes is not enough to determine the value of a specific fish feed, as enzymes act in combination with feed composition, thus when associated with metabolic parameters they are a more reliable indicator of the fish nutritional status (Lundstedt et al., 2004). Usually, fish use less carbohydrate, demanding higher protein levels in the feeds (Kikuchi, 1999). However, several researchers showed the presence of carbohydrases, such as amylase, in many fish species (Ugwumba, 1993; Hidalgo et al., 1999; Alarcón et al., 2001; Lundstedt et al., 2004).

Fish species differ greatly in their ability to digest carbohydrates. Digestive functions capable of hydrolyzing a greater variety of carbohydrate-containing feedstuffs have been developed in herbivorous and omnivorous fish, in contrast to carnivorous fish (De Almeida et al., 2006). Lower amylase levels may be indicative of the limited potential of fish to exploit diets containing high carbohydrate levels. In tambaqui (Colossoma macropomum), amylase secretion is higher in the posterior intestine (De Almeida et al., 2006). It was expected that enzymatic activities in the final intestine section of jundia would show lower values for all the experimental diets because this section is responsible for the absorption of nutrients, electrolytes, and water (Tengjaroenkul et al., 2000).

The lower amylase activities in the fish fed SY and S diets can be explained by lower dietary lipid levels 
(Table 2). In gilthead sea bream, amylase is affected by dietary fat level (Fountoulaki et al., 2005). In trout, amylase activity increases with higher consumption, temperature, and water salinity (Steffens, 1987). No variation was observed in amylase activities, even in diets with lower protein and high carbohydrate levels, in fingerling Labeo robita fed diets containing different protein levels (25 up to 40\% CP) (Debnath et al., 2007).

Acid protease is more abundant in the stomach of fishes, mainly in carnivorous species (Garcia-Carreño et al., 2002). However, high proteolytic potential is also reported in non-carnivorous fishes (Hidalgo et al., 1999; De Almeida et al., 2006). The protease observed in jundiás had great heterogeneity between diets (Table 3). No correlation was found between protease activity and growth, since jundiá fed fish meal-based diets had lower protease activities and higher growth after 90 days.

The better growth rates observed in fish fed meat and bone meal (MBS) or fish meal and soybean meal-based (FS) diets is related to the good balance and availability of essential amino acids of these feedstuffs (Tacon, 1993). In spite of their omnivorous feeding habit, jundiá requires high amount of protein in the diet, similar to some carnivorous fish (Meyer and Fracalossi, 2004). The apparent digestibility coefficients of protein and energy of soybean meal for jundia is 88.6 and $76.5 \%$, respectively (Oliveira Filho and Fracalossi, 2006). Energetic feeds showed medium values of digestibility. Soybean mealbased diets showed negative growth response in jundiá (Table 4), probably asa result of processing of the ingredient and relation with fish consumption influencing growth results.

High HSI values are usually found in fish fed diets containing high carbohydrate levels (Debnath et al., 2007). When the protein level is lower, other nutrients may be used for energy production, resulting in higher glycogen in the hepatic tissue, with increased HSI. For sunshine bass juveniles an inverse relationship between HSI and diet protein level was observed (Brown et al., 1992). No significant correlation between HSI and fish weight was recorded. Higher HSI values were reported (1.8-2.0\%) for African catfish (Clarias gariepinus) fed different soybean meal levels (Fagbenro and Davies, 2001).

Referential values herein recorded may be useful for further studies with jundiá. When juvenile jundiá were fed diets containing higher soybean meal levels (68\%), intestine alkaline protease activity was greatly affected, that is, dietary soybean meal is a potent inhibitor of alkaline proteases in jundiá and lead to reduced growth rates. $\mathrm{O}$ the other hand, jundiá shows digestive plasticity that can be modulated with diet.

\section{Acknowledgements}

To Coordenação de Aperfeiçoamento de Pessoal de Ensino Superior (CAPES), for providing a Master fellowship to R. Lazzari, and to Dr. David A. Stiles, from Western Kentucky University (USA), for language revision.

\section{References}

Alarcón, F.J.; Martinez, T.F.; Diaz, M.; Moyano, F.J. 2001. Characterization of digestive carbohydrase activity in the gilthead seabream (Sparus aurata). Hydrobiologica 445: 199-204.

Barcellos, L.J.G.; Kreutz, L.C.; Quevedo, R.M.; Fioreze, I.; Cericato, L.; Soso, A.B.; Fagundes, M.; Conrad, J.; Baldissera, R.K.; Bruschi, A.; Ritter, F. 2004. Nursery rearing of jundiá, Rhamdia quelen (Quoy \& Gaimard) in cages: cage type, stocking density and stress response to confinement. Aquaculture 232: 383-394.

Bernfeld, P. 1955. Amylases a and b: colorimetric assay methods. p. 149-158 In: Colowick, S.P.; Kaplan, N.O. Methods in enzimology. Academic Press, New York, NY, USA.

Brown, M.L.; Nematipour, G.R.; Gatlin III, D.M. 1992. Dietary protein requirement of juveniles sunshine bass at different salinities. Progressive Fish Culturist 54: 148-156.

Coldebella, I.J.; Radünz Neto, J. 2002. Soybean meal in the diets for South American Catfish (Rhamdia quelen) fingerlings. Ciência Rural 32: 499-503. (in Portuguese, with abstract in English).

De Almeida, L.C.; Lundstedt, L.M.; Moraes, G. 2006. Digestive enzyme responses of tambaqui (Colossoma macropomum) feed on different levels of protein and lipid. Aquaculture Nutrition 12: 443-450.

Debnath, D.; Pal, A.K.; Sahu, N.P.; Yengkokpam, S.; Baruah, K.; Choudhury, D.; Venkateshwarlu, G. 2007. Digestive enzymes and metabolic profile of Labeo robita fingerlings fed diets with different crude protein levels. Comparative Biochemistry and Physiology 146B: 107-114.

Fagbenro, O.A.; Davies, S.J. 2001. Use of soybean flour (dehulled, solvent-extracted soybean) as a fish meal substitute in practical diets for African catfish, Clarias gariepinus (Burchell 1822): growth, feed utilization and digestibility. Journal of Applied Ichthiology 17: 64-69.

Fountoulaki, E.; Alexis, M.N.; Nengas, I.; Venou, B. 2005. Effect of diet composition on nutrient digestibility and digestive enzyme levels of gilthead sea bream (Sparus aurata L.). Aquaculture Research 36: 1243-1251.

Garcia-Carreño, F.L.; Albuquerque-Cavalcanti, C.; Navarrete Del Toro, M.A.; Zaniboni-Filho, E. 2002. Digestive proteinases of Brycon orbignyanus (Characidae, Teleostei): characteristics and effects of protein quality. Comparative Biochemistry and Physiology 132B: 343-352.

Gomes, L.C.; Golombieski, J.I.; Chippari-Gomes, A.R.; Baldisserotto, B. 2000. Biology of jundiá Rhamdia quelen (Teleostei, Pimelodidae). Ciência Rural 30: 179-185. (in Portuguese, with abstract in English).

Hidalgo, M.C.; Urea, E.; Sanz, A. 1999. Comparative study of digestive enzymes in fish with different nutritional habits. Proteolytic and amylase activities. Aquaculture 170: 267-283.

Hummel, B.C.W. 1959. A modified spectrophotometric determination of chymotrypsin, trypsin and thrombin. Canadian Journal of Biochemistry and Physiology 37: 1393-1399.

Kaushik, S.J.; Cravedi, J.P.; Lalles, J.P.; Sumpter, J.; Fauconneau, B.; Laroche, M. 1995. Partial or total replacement of fish meal by soybean protein on growth protein utilization, potential estrogenic or antigenic effects, cholesterolemia and flesh quality in rainbow trout, Oncorbynchus mykiss. Aquaculture 133: 257274.

Kikuchi, K. 1999. Use of defatted soybean meal as a substitute for fish meal in diets of Japanese flounder (Paralichthys olivaceus). Aquaculture 179: 3-11.

Krogdahl, A.; Lea, T.B.; Olli, J.J. 1994. Soybean proteinase inhibitors affect intestinal trypsin activities and amino acid digestibilities in rainbow trout (Oncorbynchus mykiss). Comparative Biochemistry and Physiology 107: 215-219.

Krogdahl, A.; Mckellep A.M.B.; Baeverfjord, G. 2003. Effects of graded levels of standard soybean meal on intestinal structure, mucosal enzyme activities, and pancreatic response in Atlantic salmon (Salmo salar L.). Aquaculture Nutrition 9: 361-371. 
Kunitz, M. 1947. Chrystalline soybena trypsin inhibitor. II. General properties. Journal of General Physiology 30: 291-310.

Kuz'mina, V. 1990. Temperature influence on the total level of proteolytic activity in the digestive tract of some species of freshwater fishes. Journal of Ichtiology 30: 97-109.

Kuz'mina, V. 1996. Influence of age on digestive enzyme activity in some freshwater teleosts. Aquaculture 148: 25-37.

Lemieux, H.; Blier, P.; Dutil, J-D. 1999. Do digestive enzymes set a physiological limit on growth rate and food conversion efficiency in the Atlantic cod (Gadus morhua)? Fish Physiology and Biochemistry 20: 293-303.

López, M.F.J.; Martínez Díaz, I.; Díaz López, M.; Alarcón López, F.J. 1999. Inhibition of digestive proteases by vegetable meal in three fish species; seabream (Sparus aurata), tilapia (Oreochromis niloticus) and African sole (Solea senegalensis). Comparative Biochemistry and Physiology 122B: 327-332.

Lowry, O.H.; Rosebrough, N.J.; Farr, A.L.; Randall, R.J. 1951. Protein measurement with Folin-phenol reagent. Journal of Biological Chemistry 193: 265-275.

Lundstedt, L.M.; Melo, J.F.B.; Moraes, G. 2004. Digestive enzymes and metabolic profile of Pseudoplatystoma corruscans (Teleostei: Siluriformes) in response to diet composition. Comparative Biochemistry and Physiology 137B: 331-339.

Meyer, G.; Fracalossi, D.M. 2004. Protein requirement of jundiá fingerlings, Rhamdia quelen, at two dietary energy concentrations. Aquaculture 240: 331-343.

Oliva-Teles, A.; Gouveia, A.; Gomes, E.; Rema, P. 1994. The effect of different processing treatments on soybean meal utilization by rainbow trout, Oncorbynchus mykiss. Aquaculture 124: 343349.

Oliveira-Filho, P.R.; Fracalossi, D.M. 2006. Apparent digestibility coefficients of feed ingredients for jundiá juveniles. Revista Brasileira de Zootecnia S35: 1581-1587 (in Portuguese, with abstract in English).

Olli, J.; Hjelmeland, K.; Krogdahl, A. 1994. Soybean trypsin inhibitors in diets for Atlantic salmon (Salmo salar L.): effects on nutrient digestibilities and trypsin in pyloric cecca homogenate and intestinal content. Comparative Biochemistry and Physiology 109: 923-928.

Papoutsoglou, E.S.; Lyndon, A.R. 2005. Effect of incubation temperature on carbohydrate digestion in important teleosts for aquaculture. Aquaculture Research 36: 1252-1264.

Park, J.T.; Johnson, M.J. 1949. A submicro determination of glucose. Journal of Biological Chemistry 181: 149-151.
Radünz Neto, J.; Kohler, C.C.; Lewis, W.M. 1987. Water re-use system of fingerling fishes in Brasil with emphasis on South American catfishes (Rhamdia quelen and R. sapo). Tropical Agriculture 64: 2-6.

Ray, A.K. 1988. On the digestive enzymes in three Indian freshwater perches in relation to food and feeding habits. Journal of the Fisheries Society Indonesian 20: 1-5.

Refstie, S.; Storebakken, T.; Roem, A.J. 1998. Feed consumption and conversion in Atlantic salmon (Salmo salar) fed diets with fish meal, extracted soybean meal or soybean meal with reduced content of oligosaccharides, trypsin inhibitors, lectins and soy antigens. Aquaculture 162: 301-312.

SAS Institute. 1997. Statistical Analysis System: User's Guide; Version 6.08. 4. ed. SAS Institute,, North Caroline, NC, USA. $846 \mathrm{p}$.

Steffens, W. 1987. Principios Fundamentales de la Alimentación de los Peces. Acribia, Zaragoza, Spain. 275 p.

Sunde, J.; Eiane, S.A.; Rustad, A.; Jensen, H.B.; Opstvedt, J.; Nygard, E.; Venturini, G.; Rungruangsak-Torrissen, K. 2004. Effect of fish feed processing conditions on digestive protease activities, free amino acid pools, feed conversion efficiency and growth in Atlantic salmon (Salmo salar L.). Aquaculture Nutrition 10: 261-277.

Tacon, A.G.J. 1993. Feed Ingredients for Warm Water Fish: Fish Meal and Other Processed Feedstuffs. FAO, Rome, Italy., (FAO Fisheries Circular, 856).

Tengjaroenkul, B.; Smith, B.J.; Caceci, T.; Smith, S.A. 2000. Distribution of intestinal enzyme activities along the intestinal tract of cultured Nile tilapia, Oreochromis niloticus L. Aquaculture 182: 317-327.

Ugolev, A.M.; Kuz'mina, V.V. 1994. Fish enterocyte hydrolases. Nutrition adaptations. Comparative Biochemistry and Physiology 107A: 187-193.

Ugwumba, A.A.A. 1993. Carbohydrases in the digestive tract of the African bony-tongue Heterotis niloticus (Pisces: Osteoglossidae). Hydrobiologica 257: 95-100.

Uys, W.; Hecht, T. 1987. Assays on the digestive enzymes of Sharptooth Catfish, Clarias gariepinus (Pisces: Claridae). Aquaculture 63: 301-313.

Webster, C.D.; Tidwell, J.H.; Tiu, L.S. 1995. Use of soybean meal as partial or total substitute of fish meal in diets for blue catfish (Ictalurus furcatus). Aquatic Living Resources 8: 379-384.

Received March 27, 2009

Accepted February 24, 2010 